\author{
Natalia Bocian \\ Uniwersytet Łódzki
}

\title{
ETOS DZIENNIKARZA - MIT CZY RZECZYWISTOŚĆ?
}

\begin{abstract}
Wstęp
Dziennikarz to jeden z zawodów zaliczanych do grupy zawodów profesjonalnych. Podobnie jak inne zawody z tej kategorii posiada zespół reguł i zasad, które regulują etyczne postępowanie jego przedstawicieli w codziennej pracy. Czy jednak te szczytne reguły znajdują odzwierciedlenie w rzeczywistości i czy sami dziennikarze podejmują refleksję nad etycznym wymiarem swojej pracy? Kwestie etyki dziennikarskiej, czy też szerzej etyki mediów w dyskursie publicznym pojawiają się, najczęściej, przy okazji wydarzeń, zachowań dziennikarzy, niejednoznacznych pod kątem etycznym. Na co dzień dziennikarze nie poruszają chętnie tego tematu. I w zasadzie jest to słuszne, gdyż nie o rozmawianie o etyce chodzi, ale o stosowanie jej w praktyce. Czy jednak zapisy kodeksów nie są sztucznym tworem? Aby odpowiedzieć na to pytanie należałoby przeprowadzić dogłębną analizę dorobku, warsztatu wielu polskich dziennikarzy. W tym artykule autorka postanowiła zadać sobie pytanie, jak i kiedy dziennikarze piszą sami o sobie? Przedstawione zostaną wyniki krótkiej analizy treści wszystkich numerów, z okresu od stycznia do marca 2010 r., sześciu największych ogólnopolskich tygodników: Gościa niedzielnego, Polityki, Newsweek-a, Wprost, Przekroju i Przegladu. W tygodnikach autorka poszukiwała artykułów związanych z mediami - we wszystkich możliwych kontekstach. Okres analizy nie jest zbyt rozległy, jej celem było jednak pokazanie, czy na przestrzeni tak krótkiego czasu, pojawiają się jakiekolwiek artykuły, których tematem są rozważania nad stanem polskich mediów. A jeśli tak, to jak dziennikarze piszą o swoim środowisku? Co jest dla nich problemem? Czy są sytuacje, kiedy biją się w przysłowiową pierś?
\end{abstract}




\section{Kodeksy dziennikarskie w Polsce}

W książce Etyka jako filozofia dobrego działania zawodowego M. Sułka i J. Świniarskiego znajduje się następująca definicja etyki zawodowej: Etyka zawodowa jest zespotem bardziej specjalnych niż ogólnych norm i zobowiazań wymaganych od petniqcych określone funkcje zawodowe. Jest ona po prostu treściq zawarta w kodeksach deontologicznych określonych zawodów. Treść ta, ułożona w uporzqdkowany logicznie zespót norm, zwie sie „kodeksem deontologicznym" danego zawodu [Sułek, Świniarski: 2001: 63].

Etyka zawodowa, w odniesieniu do etyki normatywnej oznacza zespół norm, zasad wskazujących przedstawicielowi danego zawodu, jak powinien postępować, aby dane działanie uznać za moralne. Kształt i brzmienie owych zasad zawierają w sobie nie tylko opis tego, jak wygląda moralne postępowanie członka danego zawodu, ale również odzwierciedlać powinny oczekiwania społeczeństwa względem ludzi trudniących się daną profesją.

Etykę dziennikarską należy rozpatrywać w szerszym kontekście etyki mediów, o której Michał Drożdż mówi: Pojęcie „etyki mediów” określa catokształt teoretycznej refleksji nad mediosfera jako przestrzeniq moralności, a więc obszar ludzkich wyborów i działań medialnych. Etyka mediów, stanowiquc część etyki społecznej, obejmuje problematyke moralna, zwiazana ze strukturami i funkcjonalnościq systemów medialnych, traktowanych jako część struktur spotecznych i ekonomicznych. Etyka mediów jest teoriq moralności w obszarach szczegótowej kategorii mediów lub „produktów” medialnych (...). Stara się wypracowywać kryteria ocen etycznych obecnych w nich treśsi i form medialnych. Etyka mediów jest etyka twórców medialnych i dziennikarzy. W tym obszarze rozwija się ona jako etyka dziennikarska [Drożdż: 2006: 23]

Zaś samą etykę dziennikarską można zdefiniować za: Popularna encyklopediq massmediów: Etyka dziennikarska, postawa charakteryzująca się dqżeniem do prawdy $i$ adekwatności; bezstronnościq i uczciwościa, szacunkiem dla prywatności innych, niezależnościq od wptywu ze strony grup interesów; szacunkiem dla prawa; respektowaniem dobrych obyczajów $i$ dobrego smaku [Skrzypczak: 1999].

Jednym z podstawowych elementów sporów wokół etyki dziennikarzy jest to, czy jej podstawą powinny być normy uwzględnione w kodeksach, czy też cnoty, które dany człowiek posiada, bądź nie, a sam może je jedynie szlifować. W tym artykule autorka odniesie się tylko do tej strony medalu, którą socjologicznie można zbadać, czyli do kodeksowego ujęcia etyki dziennikarskiej. Korzeni refleksji nad etyką dziennikarską szukać należy na przełomie XIX i XX w. W 1900 r. powstał w Szwecji etyczny kodeks dziennikarzy, a 1936 r. kodeks norm międzynarodowych, który został umieszczony w dekalogu Międzynarodowej Unii Stowarzyszeń Prasowych (IUPA). Kodeks mówił o konieczności starannego sprawdzania informacji, źródeł; prostowania nieprawdziwych donie- 
sień. Kładł nacisk na obiektywność relacji oraz przestrzegał przed podejmowaniem działań, które mogłyby w jakikolwiek sposób podżegać do wojny.

Refleksja etyczna nad dziennikarstwem sięga w naszym kraju XIX w., kiedy to formułowano pierwsze kodeksy oraz funkcjonowały prasowe sądy honorowe. Jeszcze przed II wojną światową etyczne wątpliwości w środowisku medialnym rozstrzygała Prasowa Komisja Orzekająca, powstała w 1937 r. w wyniku umowy pomiędzy Związkiem Dziennikarzy RP, a Związkiem Wydawców Dzienników i Czasopism. Po zakończeniu II wojny światowej na pierwszym zjeździe Związku Zawodowego Dziennikarzy uchwalono Dziennikarski Kodeks Obyczajowy, który to z niewielkimi zmianami obowiązuje do dziś w Stowarzyszeniu Dziennikarzy Rzeczpospolitej Polskiej.

Obecnie najbardziej znanym kodeksem etyki dziennikarskiej jest Karta Etyczna Mediów, nad przestrzeganiem jej zasad czuwa Rada Etyki Mediów. Istnieją także trzy kodeksy funkcjonujące wokół trzech stowarzyszeń: Stowarzyszenia Dziennikarzy Polskich, Stowarzyszenia Dziennikarzy Rzeczpospolitej Polskiej oraz Katolickiego Stowarzyszenia Dziennikarzy. W Karcie Etycznej Mediów możemy odnaleźć zapisy odnoszące się do: konieczności podawania tylko i wyłącznie prawdziwych informacji, w sposób rzetelny i pokazujący wydarzenia w odpowiednim kontekście. Ta zasada mówi o misji mediów, którą jest mówienie prawdy i w możliwie dokładny sposób pokazywanie oraz wyjaśnianie rzeczywistości, bez prób jej zniekształcania z jakiegokolwiek powodu. Kolejny zapis traktuje o potrzebie oddzielenia informacji o pewnym fakcie od opinii dziennikarza o danej sytuacji, nawet jeśli sprawozdawca czuje, iż dotyczy ona również jego. Z tą zasadą łączy się kolejna, w której autorzy zabiegają o rzetelne oddzielanie faktów od komentarza do nich. Bardzo ważne w pracy w mediach jest działanie w zgodzie ze swoim sumieniem i przede wszystkim w trosce o dobro odbiorców. Interes widzów, słuchaczy, czytelników stoi ponad interesem dziennikarzy, wydawców, producentów, czy nadawców. Wskazuje się zatem na konieczność nie ulegania naciskom, nie działania wbrew swoim przekonaniom. W postulacie szacunku do odbiorców zawierają się także kwestie właściwego stosunku do bohaterów wydarzeń, ludzi, którzy dostarczają informacji, jak i stosunku do prywatności wszystkich podmiotów. Ostatni zapis w Karcie mówi o odpowiedzialności wszystkich „ludzi mediów” za treść i formę informacji, jakie emitują. Sygnatariusze dokumentu zobowiązali się w nim do jego przestrzegania oraz powołania Rady Etyki Mediów, której zadaniem będzie ocenianie w sprawach, w których zachodzi podejrzenie o złamanie postanowień Karty.

Zasady zawarte w Karcie odzwierciedlają wszystkie problemy związane z etycznym wykonywaniem dziennikarskiego rzemiosła. Dokument operuje filozoficznymi pojęciami, takimi jak: dobro, prawda, przekonania, odpowiedzialność, pokazując, iż samo używanie tych pojęć nie wystarczy, trzeba rozumieć ich znaczenie, dlatego Karta wyjaśnia, co to znaczy przestrzegać zasady związanej z danym pojęciem. Nie jest ona typowym kodeksem, nie koncentruje 
się jedynie na jednej grupie zawodowej, próbuje uchwycić istotę etycznego działania wszystkich ludzi mediów, a przy tym jej sformułowania są możliwie najbardziej zwięzłe.

W Polsce powszechnie znane w środowisku medialnym są jeszcze trzy kodeksy, związane z działalnością trzech stowarzyszeń.

Pierwszym z nich jest Kodeks Etyki Dziennikarskiej Stowarzyszenia Dziennikarzy Polskich, w którym za główne zadanie dziennikarzy uznaje się przekazywania rzetelnych oraz możliwie bezstronnych informacji. W dokumencie tym uznaje się, iż wartości wolności i odpowiedzialności muszą być traktowane jako równorzędne oraz uzupełniające się wzajemnie, zatem wolności mediów musi bezwzględnie towarzyszyć odpowiedzialność tak dziennikarzy, jak i nadawców radiowych i telewizyjnych oraz wydawców prasowych za publikowane informacje. Jednocześnie w Kodeksie zaznaczone zostało, iż pracy dziennikarzy powinna przyświecać misja służenia interesowi społeczeństwa, przedkładanie go ponad własny.

Drugim istotnym kodeksem jest Kodeks Stowarzyszenia Dziennikarzy Rzeczpospolitej Polskiej, nazwany Kodeksem Etyki Dziennikarzy. Podzielony jest na piętnaście paragrafów mówiących o zasadach etycznych w pracy dziennikarza oraz odpowiedzialności członków Stowarzyszenia za przestrzeganie tych uregulowań. Za najważniejsze zadanie, jakie stoi przed dziennikarzami uznaje się poszukiwanie oraz publikację wyłącznie prawdziwych i sprawdzonych informacji. W dokumencie tym uznaje się, iż wartości wolności i odpowiedzialności muszą być traktowane jako równorzędne oraz uzupełniające się wzajemnie, zatem wolności mediów musi bezwzględnie towarzyszyć odpowiedzialność tak dziennikarzy, jak i nadawców radiowych i telewizyjnych oraz wydawców prasowych za publikowane informacje. Jednocześnie w Kodeksie zaznaczone zostało, iż pracy dziennikarzy powinna przyświecać misja służenia interesowi społeczeństwa, przedkładanie go ponad własny. Zasady ujęte w dokumencie zostały pogrupowane $\mathrm{w}$ przedmiotowe kategorie. I tak mamy zapisy dotyczące treści i formy oraz sposobów zbierania i opracowywania informacji. Zapisy Kodeksu zawierają również wskazówki, co do właściwych relacji dziennikarza z odbiorcami. Zawiera on również wskazówki postępowania w momencie konfliktu interesów. Ostatnią kategorią tematyczną jest obszar odpowiedzialności oraz kar. Za naruszenia wyżej opisanych postanowień odpowiada zarówno autor publikacji, jak i redaktor, wydawca, bądź nadawca.

Uzupełnieniem tego obrazu jest Kodeks Etyki Dziennikarskiej Katolickiego Stowarzyszenia Dziennikarzy, który ma niemal identyczne brzmienie, jak ten obowiązujący w Stowarzyszeniu Dziennikarzy Polskich, gdyż jest opracowany na podstawie tego ostatniego.

Przedstawione tu kodeksy obowiązują tylko członków danego stowarzyszenia, lecz zaraz po Karcie Etycznej Mediów są to trzy najbardziej znane kodeksy. Treści poruszane we wszystkich przedstawionych dokumentach poruszają się 
wokół tych samych obszarów, ważnych dla środowiska dziennikarskiego tematów i w większości są tożsame z zasadami zawartymi w Karcie. Dopełnieniem obowiązujących kodeksów jest oczywiście stanowione prawo oraz ustawy regulujące działalność ludzi mediów, w tym dziennikarzy. Prawami i obowiązkami tych ostatnich zajmują się następujące zapisy:

- Prawo prasowe; Ustawa z dnia 26 stycznia 1984 r. (DzU 1984, nr 5, poz. 24 z późn. zm.);

- Prawo do uzyskania informacji publicznej; Ustawa z dnia 6 września 2001r. o dostepie do informacji publicznej (DzU 2001, nr 112, poz. 1198);

- Obowiązki dziennikarzy Telewizji Publicznej wynikające z jej zadań; Ustawa o radiofonii i telewizji z dania 29 grudnia 1992 r. (DzU 2001, nr 101, poz. 1114);

- Obowiązki dziennikarzy wynikające z procedury karnej; Ustawa z dnia 19 kwietnia 1969 r. Kodeks karny (DzU z dnia 14.05.1969).

\section{Media o mediach - wyniki analizy treści}

Przeprowadzone badanie obejmuje okres od stycznia do marca 2010 r. Do próby wziętych zostało sześć tzw. tygodników opinii (w tym jeden katolicki) o największych nakładach na rynku (od ponad 200 tys. do około 70 tys.). Zanalizowane zostały wszystkie numery Gościa niedzielnego (12 numerów), Polityki (13 numerów), Newsweek-a (13 numerów), Wprost (13 numerów), Przekroju (13 numerów) i Przeglądu (12 numerów), które ukazały się w tym okresie.

Analizując wybrane tygodniki autorka poszukiwała po pierwsze artykułów związanych z mediami. Po drugie zaś w samych tekstach chciała odnaleźć uzewnętrznione zasady zawarte w Karcie Etycznej Mediów. Okazało się, iż w analizowanych tygodnikach temat ten nie gości często na ich łamach. Najwięcej takich artykułów ukazało się w Polityce - osiem, sześć w Newsweek-u, cztery w Przekroju, dwa w Gościu niedzielnym, najmniej o mediach pisał Wprost i Przeglad - pojawiło się tylko po jednym artykule w każdym z czasopism, spełniającym kluczowe kryterium. Choć liczba artykułów okazała się niewielka, zastane artykuły zostały pogrupowane w trzy kategorie tematyczne:

1) artykuły o ludziach mediów,

2) artykuły traktujące o problemach polskich mediów publicznych,

3) artykuły o brutalizacji mediów.

Podstawowym kryterium takiej klasyfikacji stała się problematyka dominująca w poszczególnych artykułach. Do pierwszej kategorii, obejmującej tematykę ludzi mediów zakwalifikowano najwięcej artykułów - dziesięć: jeden w Gościu niedzielnym, jeden z Newsweek-a, cztery z Przekroju, jeden z Wprost, trzy z Polityki. Znalazły się tu artykuły traktujące o takich osobach, jak: Ryszard 
Kapuściński, Jacek Sobala, Edward Miszczak, Ewa Wanat, Tomasz Sekielski, o. Wojciech Jędrzejewski, Romuald Orzeł. Za ludzi mediów uznaje się w niniejszym artykule dziennikarzy, publicystów, reportażystów, wydawców. W drugiej grupie obejmującej publikacje dotyczące upolitycznienia mediów publicznych znalazło się sześć artykułów: cztery z Newsweek-a i po jednym z Gościa niedzielnego i Polityki. Trzecia kategoria objęła sześć artykułów, traktujących o brutalizacji mediów: po jednym w Newsweek-u i Przegladzie oraz cztery w Polityce.

Kolejny etap analizy miał na celu odnalezienie werbalizacji siedmiu zasad zapisanych w Karcie Etycznej Mediów. W publikacjach szukałam zasad: prawdy, obiektywizmu, oddzielania informacji od komentarza, uczciwości, szacunku i tolerancji, pierwszeństwa odbiorcy oraz wolności i odpowiedzialności. Przeprowadzone badanie miało na celu zanalizowanie tych kategorii w dwóch wymiarach: wymiarze istnienia (Existence), który odzwierciedla to, ile razy dana kategoria pojawia się $\mathrm{w}$ materiale oraz $\mathrm{w}$ wymiarze wartości (Values), gdzie w wypowiedziach szukać należy ich pozytywnego, negatywnego oraz neutralnego charakteru. W obrębie szukanych kategorii - zasad pochodzących z Karty Etycznej Mediów zostanie zachowany, przedstawiony wyżej, podział artykułów na: publikacje o ludziach mediów, problemach polskich mediów publicznych oraz brutalizacji mediów.

Pierwszą szukaną kategorią jest: zasada prawdy, mówiąca o tym, iż: (...) dziennikarze, producenci, wydawcy i nadawcy doktadaja wszelkich starań, aby przekazywane informacje byty zgodne z prawda, sumienne $i$ bez znieksztatceń relacjonujace fakty $w$ ich wtaściwym kontekście, a $w$ razie rozpowszechnienia btędnej informacji niezwłocznie dokonuja sprostowania [Karta Etyczna Mediów: 1995]. Kategoria ta pojawiła się we wszystkich tekstach 12 razy.

W pierwszej grupie tematycznej: artykułów o ludziach mediów kategoria ta pojawiła się pięć razy. W każdym przypadku jest ona użyta w negatywnym sensie, tzn. iż autorzy tekstów zaznaczają, iż nie zawsze przestrzeganie tego szczytnego zapisu staje się priorytetem. Wszystkie wypowiedzi, jakie się tu znalazły dotyczą osoby Ryszarda Kapuścińskiego i gorącej dyskusji przed oraz po publikacji książki Artura Domosławskiego Kapuściński non-fiction. W zbiorze tym znalazły się, m. in. takie wypowiedzi, jak: Reportaż jest rzemiostem sprowadzajacym się do relacjonowania faktów - $i$ to najlepiej takich, których reporter byt naocznym świadkiem. Tego właśnie oczekuje czytelnik. Siła rzeczy ograniczać to musi dowolność $w$ posługiwaniu sie rozmaitymi środkami artystycznymi. To wiarygodność, a nie zabawa forma - także ta stużaca podniesieniu atrakcyjności czytelniczej-jest istota tego gatunku. Tymczasem Domosławski punkt po punkcie dowodzi, że jego - i catych pokoleń polskich dziennikarzy - mistrz od poczatku dość swobodnie traktowat faktograficznq strone swojej twórczości. Efekt i dramatyzm narracji przeważały często nad wiernościa faktom [Polityka: 2010: nr 11] Bądź też kolejny pogląd: W redakcji „Gazety Wyborczej” (...), gdzie pra- 
cuje elita reportażystów, funkcjonuje określenie „polecieć Baderem”. W ostatnim wydaniu branżowego miesięcznika „Press” rozszyfrowat je sam Jacek Hugo-Bader: „Redaktor mówi tak do dziennikarza, gdy ten przynosi mu nudny tekst. Trzeba opukiwać temat tak dtugo, aż doskrobiesz się czegoś wartego opisania" - mówi reportażysta [Newsweek: 2010: nr 13]. Pisząc o prawdzie, autorzy wyselekcjonowanych tekstów podkreślają, jak ważne ma ona znaczenie w gatunkach dziennikarskich. Pomimo, iż reportaż formalnie jest forma literacka, dla odbiorców często jawi się jako relacja oddająca rzeczywistość, jeśli reportażysta zbyt mocno ją koloryzuje to przestaje ona być jej odzwierciedleniem, a staje się fikcją umiejscowioną w realnym krajobrazie.

Kategoria prawdy w artykułach traktujących o problemach polskich mediów publicznych pojawiła się dwa razy. W obu przypadkach były to wypowiedzi świadczące o nie stosowaniu tej zasady w praktyce. Wypowiedzi wiążą się z tematem objęcia kierownictwa Trzeciego Programu Polskiego Radia przez Jacka Sobalę i pochodzą z wypowiedzi Wojciecha Manna. Mówi on m. in.: Telewizja upolityczniona była zawsze. W telewizji nigdy nie było tez niczego dla mnie tak ważnego, jak Program Trzeci w radiu. Chociaż może jest to mikroskopijna paralela. Przecież więdnie TVP Kultura, która jest taka telewizyjnq minitrójka, schroniskiem dla ludzi, którzy majq ochotę ustyszeć coś więcej niż „,heja” [Newsweek: 2010: nr 10]. W drugiej wypowiedzi Mann stwierdza: Niestety, to, co się dzieje teraz w Trójce, przypomina mi PRL. Jeśli prezes Polskiego Radia Jarostaw Hasiński mówi, że „dynamika wzrostu stuchalności Trójki jest niewystarczajaca", to ja stysze przestraszliwe kłamstwo i komunistycznq nowomowe. Już przerabiatem te metody zmiękczania ludzi. Wtaśnie w PRL [Newsweek: 2010: nr 10]. Te wypowiedzi pokazują próbkę poglądu, co prawda jednego dziennikarza, ale wypowiadającego się niejako w imieniu większości dziennikarzy Trójki. Całość wywiadu z Mannem, dziennikarzem muzycznym, dała świadectwo tego, iż bliskie są mu ideały związane $\mathrm{z}$ etycznym postępowaniem w obrębie profesji, którą reprezentuje, nie tylko prawdy, ale i uczciwości, odpowiedzialności, poszanowania wolności oraz dbania o dobrze rozumiany interes odbiorcy.

Trzecia grupa tematyczna obejmuje artykuły obrazujące postępującą brutalizację polskich mediów. W zbiorze tym dominują teksty, które próbują pokazać to zjawisko, które bardzo nasila się w tzw. prasie brukowej. Autorzy próbują tym tendencjom przeciwstawić tzw. dziennikarstwo wysokie, aczkolwiek znalazłam też wypowiedzi mówiące o tym, iż brutalizacja zaczyna obejmować także „poważne” media. Dawniej ustalone granice dobrego smaku, szacunku i profesjonalizmu tracą racje bytu. Zasadę prawdy, a raczej opinie o braku jej stosowania odnotowano w tekstach pięć razy. Tak o tabloidach pisano w Polityce: Nie ma wyważenia racji, uwzględnienia wszystkich komplikacji, jakie zwykle niesie życie, także w tej sprawie. Komplikacje nie nalezq do tego świata zwyktych ludzi, sq ciałem obcym i niepożądanym. Ale też usunięcie wszelkich watpliwości powo- 
duje, że rzeczywistość przedstawiana $w$ tabloidach, niezdrowo pobudzona, naładowana negatywnymi emocjami, jest, $w$ najgłęsszym sensie, całkowicie fatszywa [Polityka: 2010: nr 2]. Bezgraniczne łamanie zasady prawdy jeden z autorów tekstu puentuje: Nie sposób uwolnić się od silnego poczucia, że zostaliśmy, trochę na własne życzenie, złapani w jakaś sieć kłamstwa. Kłamstwo polega przede wszystkim na tym, że gazety sensacyjne nie przynależa do zbioru prasy, sq tylko wyrobami prasopodobnymi. Nie sq wydawane po to, by przyblizyć nas do jakiejkolwiek prawdy, wydawane sa po to, by zarobić [Polityka: 2010: $\mathrm{nr}$ 2].

Drugą poszukiwaną kategorią była zasada obiektywizmu, którą w analizowanych tekstach odnaleziono 11 razy. Zasada ta oznacza, iż autor przedstawia rzeczywistość niezależnie od swoich pogladów, rzetelnie relacjonuje różne punkty widzenia [Karta Etyczna Mediów: 1995].

W pierwszej grupie - publikacji o ludziach mediów kategoria pojawiła się jeden raz w kontekście negatywnym. Autor tekstu o Ewie Wanat przytacza jej słowa o radiu TOK FM, w których stwierdza ona, iż ,jej" radio z pewnością nie jest obiektywne, zaznaczając jednocześnie, iż jest adresowane do ukształtowanych odbiorców, którzy mają już wyrobiony światopogląd i w związku z tym afiliacje radia nie zniekształcają im odbioru rzeczywistości, a jedynie komentują ją zgodnie z pewnymi poglądami. Pomimo, iż wyraźne jest tu pokazanie nie przestrzegania zasady obiektywizmu to jednocześnie podkreśla się wyjątkową pozycję radia, które w jakiś sposób poprzez swoją formułę wychodzi naprzeciw odbiorcom, stawiając na pierwszym miejscu ich oczekiwania.

W drugiej grupie odnaleziono tę kategorię pięć razy. Ponieważ teksty w tym zbiorze dotyczą problemów mediów publicznych to słusznie można domyślać się, iż we wszystkich przypadkach była ona użyta w negatywnym znaczeniu. Niemal we wszystkich tekstach pojawia się zarzut braku obiektywności w polskich mediach publicznych oraz przede wszystkim znacznego ich upolitycznienia: Media publiczne niezależne sq tylko teoretycznie. Ich wtadze powotywane sq $w$ politycznym przetargu. Parlament i prezydent powotuja Krajowa Rade, do której deleguja swoich [Polityka: 2010: $\mathrm{nr}$ 8]. W podobnym tonie pisze Newsweek o prezesie TVP Romualdzie Orle: Czy jednak pod kierownictwem nowego zarzadu nie grozi nam radykalne upolitycznienie programu Telewizji Polskiej? Zapewne tak. Tym bardziej, że pewne symptomy już widać - programy informacyjne Jedynki zaczynaja skręcać w kierunku PiS, a w Dwójce zaczyna dominować lewica [Newsweek: 2010: $\mathrm{nr}$ 1].

Problem braku obiektywizmu w tekstach zaliczonych do trzeciej kategorii artykułów o brutalizacji mediów - pojawił się pięć razy. Zarzuty te dotyczyły głównie prasy plotkarskiej, gdzie ferowanie wyroków bez sądu, a często choćby realnych przesłanek jest nazbyt częste. Dziennikarze zwracają uwagę na brak wyciagania konsekwencji wobec pism cechujących się podobną niefrasobliwością. W artykule, który ukazał się w ósmym numerze Przegladu negatywne oceny, w kontekście tej zasady, otrzymała publicystyka, zarówno ukazująca się 
w telewizji publicznej, jak i dużej komercyjnej stacji - TVN: (...) okazuje się więc, że główny nurt (publicystyki - przyp. aut.) jest de facto bardzo ubogi i jednostronny. Że z polska publicystyka jest jak z ubogim targowiskiem. Różnia się tylko sprzedawcy (dziennikarze), jedni sq bardziej agresywni, drudzy mniej, natomiast towar, który oferuja, jest ten sam - z hurtowni [Przegląd: 2010: nr 8].

Trzecią poszukiwana przeze mnie kategorią była zasada oddzielania informacji od komentarza, której istotą jest umożliwienie odbiorcy odróżnienie faktów od opinii i komentarzy [Karta Etyczna Mediów: 1995]. Kategoria ta pojawiła się w analizowanym materiale 7 razy. W artykułach traktujących o ludziach mediów problem ten pojawił się trzy razy. Wystąpił w tekstach dotyczących kontrowersji wokół twórczości Ryszarda Kapuścińskiego oraz ogólnie polskich reportażystów, którym to zdarza się niezauważalnie dla odbiorców łączyć płaszczyzny: informacji i komentarza. Przy okazji tych rozważań po raz kolejny pojawiła się kwestia tego, jak rozróżnić to, co w reportażu jest sprawozdaniem z rzeczywistości, a co już literackimi kolorami historii. Dyskusja oczywiście nie została rozstrzygnięta, ale samo jej zawiązanie jest pozytywną informacją.

Co ciekawe, temat oddzielania komentarza od informacji nie wystapił w artykułach dotyczących problemów polskich mediów publicznych. Być może jest to spowodowane tym, iż główną bolączką okazało się upolitycznienie tych instytucji, brak obiektywizmu. Z góry zakłada to podawanie informacji w pewien sposób z góry nacechowanych poglądami, intencjami dziennikarzy, czy nadawców.

W trzecim zbiorze tematycznym - dotyczącym brutalizacji mediów, zasada oddzielania informacji od komentarza pojawiła się cztery razy w negatywnym kontekście. Odnalezione przeze mnie opinie także i tu, w znacznej mierze, tyczyły się prasy brukowej. W jednej z nich czytamy: Tabloidy czuja sie zwolnione z prawdziwej analizy, np. ekonomicznej, płynnie podażaja za populistycznym nurtem, gdzie się należy tym, którzy sa krzywdzeni, czyli czytelnikom [Polityka: 2010: $n$ r 2].

Czwarta zasada mówi o uczciwości, co oznacza postępowanie w zgodzie z własnym sumieniem i dobrem odbiorcy, nieuleganie wpływom, nieprzekupność, odmowe działania wbrew przekonaniom [Karta Etyczna Mediów: 1995].

Opinie o uczciwości medialnej pojawiły się w artykułach o ludziach mediów cztery razy. W jednym przypadku była to wypowiedź pozytywna i dotyczyła radia TOK FM, które może i nie jest obiektywne, ale otwarcie mówi o swoich liberalnych afiliacjach, zatem słuchacze są świadomi, jakich treści mogą się w nim spodziewać. Negatywne opinie dotyczyły po raz kolejny oceny twórczości reporterskiej Kapuścińskiego, ale również metod postępowania Jacka Sobali, któremu właśnie brak uczciwości w decyzjach dotyczących radia publicyści zarzucają.

Polskie media publiczne nie zyskały dobrych ocen, jeśli chodzi o działanie w zgodzie z zasadą uczciwości. Ta kategoria pojawiła się pięć razy, w tym raz 
miała pozytywny charakter. Negatywne opinie koncentrowały się na sytuacji w radiowej Trójce po objęciu rządów przez Jacka Sobalę. W Gościu niedzielnym Romuald Orzeł mówił o kompletnym upolitycznieniu mediów publicznych i problemów, jakie się z tym wiążą tak dla niego jako prezesa, jak i dla współpracujących dziennikarzy: Debatujemy o mediach publicznych od wielu lat, natomiast za określenie ich roli i tak biorq się zawsze politycy. Czy można się odżegnać od polityki przy tak zdefiniowanych mediach? Nie. Wiadomo, że o losie rad nadzorczych, które potem powołuja zarzady tych mediów, decyduje Krajowa Rada Radiofonii i Telewizji, a konstrukcja jej wyboru jest jednak polityczna [Gość Niedzielny: 2010: nr 4]. Pozytywna wypowiedź również dotyczyła Trójki, tak o własnej uczciwości z samym sobą i słuchaczami mówi Wojciech Mann: Po przerwie spowodowanej wprowadzeniem stanu wojennego Trójka na nowo ruszyła w kwietniu 1982 r. Jak wszedtem do studia jesienia, bardzo się batem. Nigdy nie dostatem ani jednego listu, że się wtedy sprzedatem. Przypominam sobie za to kartke pocztowa od stuchaczki: „Bardzo mi miło, że moge postuchać audycji, w której nie mówi się o tym, kiedy Feliks Dzierżyński złamat rękę, wypetniajac obowiazki stużbowe, tylko nadaje się rock'n'rolla [Newsweek: 2010: nr 10].

W tekstach o brutalizacji mediów odnaleziono dziesięć opinii o przestrzeganiu zasady uczciwości w mediach - wszystkie były negatywne. Dziennikarze zwracają uwagę na wypaczanie rzeczywistości przez media plotkarskie, nie dbanie o dobrze rozumiany interes odbiorcy, a jedynie dążenie do generowania zysków za wszelką cenę i wszelkimi sposobami. Wyraźnie starają się przeciwstawiać takiemu stylowi uprawiania dziennikarstwa i utożsamianiu z nim mediów w ogóle. $\mathrm{W}$ jednym $\mathrm{z}$ artykułów publicyści przywołują anegdotę, tracącą czarnym humorem: Jeden z nas (...) przeżyt niedawno taka oto przygodę. Podat taksówkarzowi adres redakcji i przy wysiadaniu z taksówki ustyszat: ale ma pan świetny zawód, nakłamie pan, nakłamie i jeszcze panu za to płacą [Polityka: 2010: nr 2]. Dziennikarzom zdarza się jednak piętnować także, tzw. poważne media, które jak głosi tytuł jednego z artykułów w Przegladzie podążają albo $\mathrm{w}$ stronę show, albo propagandy, całkowicie porzucając ideały bycia uczciwym dziennikarzem. Autorzy sugerują, iż istnieją w polskich mediach pewne kalki, które nakłada się na wydarzenia, które nadają im każdorazowo ustalone przez tę kalkę znaczenie i wartość: media w Polsce rzadzq się swoistym niepisanym kodeksem poprawności politycznej. Że istnieja kalki pojęciowe, które dziennikarze przyjmuja za „oczywistq oczywistość”, że istnieja tematy tabu, które skrupulatnie omijaja. A wszystko to ogranicza pole debaty, czyni ja nieautentyczna, czqstkowq. Tygodnik pisze o wybiórczym charakterze samej KRRiT, która ukarała radio TOK FM za niepoprawną politycznie wypowiedź na antenie (w programie na żywo) Andrzeja Czeczota. Organ zamiast być strażnikiem wolności i odpowiedzialności mediów w politycznych rękach staje się politycznym narzędziem „załatwiania” interesów. 
Piąta zasada mówi o szacunku i tolerancji, a zatem poszanowaniu ludzkiej godności, praw osobistych, a w szczególności prywatności $i$ dobrego imienia [Karta Etyczna Mediów: 1995]. W analizowanym materiale pojawiała się 6 razy. W grupie tekstów o ludziach mediów odnalazłam ją dwa razy. Za każdym razem wskazywano na przekroczenie granic tej zasady. Obie wypowiedzi dotyczyły postępowania Jacka Sobali. Autor artykułu o nowym dyrektorze Trójki pisze m. in.: Szerokim echem odbiła się audycja Sobali z poczatku roku 2000, w której rozprawiat się z Ryszardem Benderem, prawicowym politykiem $i$ publicysta. Prezenter wezwat stuchaczy do ,bicia $w$ morde każdego rasisty” [Przekrój: 2010: nr 3]. W artykułach o problemach polskich mediów publicznych nie pojawiły się wypowiedzi mówiące o tej zasadzie, czy to w pozytywnym, czy negatywnym charakterze.

Trzecia grupa tematyczna obejmowała teksty o brutalizacji polskich mediów. Zasada szacunku i tolerancji wystapiła w nich czterokrotnie. Za każdym razem były to wypowiedzi negatywne. W analizowanych tekstach zarzuca się, głównie mediom brukowym, brak poszanowania właśnie dla ludzkiej godności, nagminne łamanie prawa do prywatności i dobrego imienia. Warto przytoczyć tu dwie wypowiedzi z artykułu: Prasa na bruku, który ukazał się w Polityce: Motyw religijny jest bardzo $w$ tej prasie obecny, $w$ czym nie przeszkadza fotka nagiej kobiety, towarzyszaca a to brytyjskiej królowej, wsiadajacej do zwykłego pociagu, a to informacji o nieślubnym synu Putina. I tu jednak nie udaje sie uniknqć odrażajacej pornografii, kiedy „Fakt” publikuje damski biust tuż pod tytułem: „Zattukli człowieka kamieniami”, z drastycznym zdjęciem zakrwawionych zwtok. To jest granica, którq brukowce przekraczaja i nadal żadaja szacunku [Polityka: 2010: nr 2]. I kolejna: (...) to charakterystyczne traktowanie ludzi jak towar: to tylko „ryje”, które trzeba sfotografować w kompromitujacych albo przynajmniej dziwacznych sytuacjach [ibidem].

Piąta i z pewnością niezwykle ważna zasada mówi o pierwszeństwie dobra odbiorcy. Zwraca ona uwagę, iż podstawowe prawa czytelników, widzów i stuchaczy sq nadrzędne wobec redakcji, dziennikarzy, wydawców, producentów i nadawców [Karta Etyczna Mediów: 1995]. W analizowanych tekstach pojawiła się 10 razy.

Kategorię odnaleziono pięć razy w pozytywnym charakterze w grupie tekstów o problemach mediów publicznych. Autorzy zwracali uwagę na rozmaite przejawy tej zasady oraz pomysły, jak ją realizować. Ciekawym jest fakt, iż pomimo zgody, co do zjawiska upolitycznienia tych mediów, można jako dziennikarz działać w zgodzie z tą zasada. Wojciech Mann stwierdza: Jeśli tak dalej pójdzie, to nie widzę się w Trójce. Nie chce mówić o misji, ale obowiazuje mnie uczciwość wobec stuchaczy [Newsweek: 2010: nr 10]. Jacek Żakowski o pomyśle projektu nowych mediów publicznych: Chodziło o to, by stworzyć prawdziwie publiczne, niezależne od polityków media, dajace Polakom dostęp do dobrych filmów, rzetelnej informacji, kompetentnej publicystyki, wartościowej 
rozrywki, programów edukacyjnych na przyzwoitym poziomie i rozwijajacych audycji dla dzieci [Polityka: 2010: nr 8].

Zasada pierwszeństwa pojawiła się siedem razy w tekstach o brutalizacji mediów - tu jednak nacechowana była ona negatywnie. Publicyści zarzucają mediom plotkarskim złe rozumienie tej zasady, chowanie się za nią i usprawiedliwianie za jej pomocą stosowania wszelkich dostępnych środków. W artykule Prasa na bruku czytamy: Kto nie huśta i nie organizuje igrzysk, nie ma widzów i stuchaczy, nie ma czytelników. A czytelnicy chca coraz więcej sensacji i afer, bo media ścigaja się, by im ich dostarczyć. Bronisław Łagowski mówił „Gazecie Wyborczej”: Ludzie domagaja się ścigania, bez ogladania się na swobody obywatelskie, pragna igrzysk, nie sprawiedliwości [Polityka: 2010: nr 2]. W cytowanym już artykule Show czy propaganda? błędne interpretowanie tej zasady zarzuca się także ,poważnym” mediom: (...) szefowie TVN krok po kroku wycofali się z formuty ambitnej telewizji, zamieniajac ja w masowa, adresowanq do mieszkańców wielkich miast. Mariusz Walter tłumaczyt ten ruch bez ogródek - decyduja stupki ogladalności. Jeśli więc jakiś program te stupki zaniża, trzeba go zastapić innym. Ta filozofia została zaszczepiona pracujacym w TVN dziennikarzom. Tomasz Lis w rozmowie z "Przegladem", gdy opowiadat o swym programie "Co z ta Polskq?", wiele mówit o stupkach ogladalności. Że nie może sobie pozwolić na gtębsza rozmowę, zawierajaca mniej emocji, bo natychmiast ogladalność leci $m u w$ dót. Musi więc zapraszać gości, którzy przyciagna widza, i prowadzić program $w$ takiej temperaturze, by tego widza utrzymać [Przeglad: 2010: nr 8]. $\mathrm{W}$ artykule podaje się kolejny przykład nadgorliwości w przypodobaniu się widzom w wydaniu dziennikarzy Teraz my i programu z Wojciechem Jaruzelskim, w którym prowadzili z nim bardzo brutalny i agresywny wywiad: (...) mówili oni $w$ wywiadzie dla „Polska. The Times”, że zależało im na wzbudzeniu emocji, że ta droga szukali sukcesu. Wzbudzenie emocji u telewidzów okazało się ważniejsze niż próba pogłębienia wiedzy, zrozumienia tamtych czasów. Jednym słowem dziennikarze chcieli show. I to w ten sposób, że chcieli pognębić Jaruzelskiego, skonfundować go, obsadzajac $w$ roli tego złego, któremu oni daja radę. I to zupetnie się im nie udało (...) Ale czy można im się dziwić? Dziennikarze „Teraz My” popłynęli w gtównym nurcie dziennikarskiej poprawności. Z jednej strony, chcieli stworzyć widowisko, będac najwyraźniej przekonani, że tego oczekuja od nich widzowie. $Z$ drugiej strony, obsadzili się w roli egzekutorów gen. Jaruzelskiego jako tego, który sttumit polskq wolność. Za co zreszta byli chwaleni przez prawicowa prasę, choć na pewno nie przez telewidzów. Ostatnią szukaną przez mnie kategorią była zasada wolności i odpowiedzialności. Zakłada ona, iż wolność mediów nakłada na dziennikarzy, wydawców, producentów, nadawców odpowiedzialność za treść i forme przekazu oraz wynikajace z niej konsekwencje [Karta Etyczna Mediów: 1995]; kategoria ta wystapiła 25 razy.

Zasadę tę odnaleziono cztery razy w artykułach dotyczących ludzi mediów, za każdym razem w kontekście negatywnym. Zazwyczaj dziennikarze upominają 
swoich kolegów o jej nadużywanie. W jednym z artykułów przedstawiono natomiast jej łamanie ze strony KRRiT, która to szósty raz w ciagu ostatnich pięciu lat upomniała TOK FM, tym razem za wypowiedź na żywo Andrzeja Czeczota. Autor pisze o planach Ewy Wanat zaskarżenia KRRiT za nękanie jej stacji, zarzutem jest $\mathrm{m}$. in. ograniczanie przez KRRiT prawa do swobody wypowiedzi.

$\mathrm{W}$ artykułach o problemach polskich mediów publicznych poruszano ten problem dziesięć razy. Każdorazowo w negatywnym kontekście. Zarzucano mediom z jednej strony ograniczanie tej wolności, z drugiej zaś nie branie odpowiedzialności za jej nadużywanie. Tak o dziennikarzach Trójki mówi Wojciech Mann: Nie możemy być bydtem przeganianym z miejsca na miejsce przez polityków [Newsweek: 2010: nr 10]. O tym, że media publiczne nadużywaja wolności czytam w jednym z artykułów Newsweeka: Niedawno również do studia TVP Info zaproszony zostat PRL-owski dziennikarz $i$ wspótpracownik wywiadu PRL Eugeniusz Guz, który na antenie powtarzat komunistycznq teze, że zamach na papieża Jana Pawła II w 1981 roku mógt być dziełem CIA. Nikt w TVP nie zostat ukarany za ten występ [Newsweek: 2010: $\mathrm{nr} 10]$ ] W tej grupie tematycznej pojawił się także wątek kary dla TOK FM w kontekście ograniczania wolności słowa temu nadawcy. Romuald Orzeł, w wywiadzie, którego udzielił Gościowi niedzielnemu mówi o odpowiedzialności telewizji publicznej i trudnościach w realizowaniu tej zasady wobec pozbawienia jej środków w postaci abonamentu: Ja sobie nie wyobrażam, by media publiczne zostały pozbawione misyjności. Tylko musimy mieć świadomość, oceniajac dzisiejsza telewizję, że jakiś serial, lepszy lub gorszy, w tej chwili pracuje nie tylko na siebie, ale tez na wszystkie inne propozycje: na dokument, reportaż, teatr, które nie sq $w$ stanie na siebie zarobić. Sytuacja jest teraz na tyle dramatyczna, że możemy jedynie wprowadzić program ekonomiczno-naprawczy.

Również w artykułach dotyczących brutalizacji mediów ta kategoria pojawiła się wielokrotnie - 15 razy. Także w tej grupie była ona nacechowana negatywnie. Zarzuty o nadużywanie tej wolności były kierowane głównie pod adresem mediów plotkarskich, zwracano jednak uwagę na „tabloidyzację” mediów poważnych. Przeglad przytacza słowa Wiesława Gałązki: Jeżeli media sq wolne, to sq także wolne od rozumu - mówi Wiesław Gałazka - Jeśli chodzi o publicystykę polityczna, to dominuje u nas walka psów. Zaprasza się dwóch polityków, $w$ środku dziennikarz, i szczuje jednego na drugiego. A jeśli dochodzi do sytuacji, kiedy jeden z adwersarzy ma wreszcie coś ciekawego do powiedzenia, dziennikarz mu przerywa, zadaje pytanie albo kończy dyskurs. Bo odpowiedź nie może być dtuższa niż 180 sekund - tak dtugo wedtug badań jest $w$ stanie skupić się telewidz. Polskie programy nie pokazuja też pozytywnych wzorców, nie pokazuja ludzi pracowitych, kompetentnych, dobrych gospodarzy, których nie brakuje. Zamiast tego widzimy awanturników, ludzi posęnych, podtych. U widza rodzi się więc poczucie bezradności: kto nami rzadzi? [Przeglad: 2010: nr 8]. Jednym z wydarzeń, które wywołały dyskusję nad granicami wolności mediów, 
była publikacja zdjęć senatora Piesiewicza, a przede wszystkim fakt zakupienia ich od przestępców. W artykule Prasa na bruku czytamy: chyba nigdy wcześniej, tak jak dzisiaj, w nowej Polsce, nie zajmowano się równie namiętnie kwestia, czy prasa nie nadużywa swoich praw do informacji, czy wolno jej wszystko i na czym powinna polegać rola dziennikarzy w prześwietlaniu życia osób publicznych. W tej dyskusji udziat biorq także sami dziennikarze, jedni w todze obrońców praw do opisywania i pokazywania dosłownie wszystkiego ( $z$ reguty zresztq uprawiajacy osobiście ten rodzaj dziennikarstwa), i inni, widzacy potrzebe wyznaczenia jakichś granic przed catkowita dowolnościq $i$ opowiadajacy sie za świadomym samoograniczeniem czy wręcz karnym ograniczaniem prawa do niepohamowanej twórczości dziennikarzy i redaktorów [Polityka: 2010: nr 2].

\section{Podsumowanie}

W części teoretycznej artykułu powiedziano o „etycznym” zapleczu dziennikarzy i szerzej - ludzi mediów w Polsce. Poprzez krótkie badanie autorka chciała sprawdzić, czy temat etyki zawodowej pojawia się w zwerbalizowanej refleksji samych dziennikarzy. W wybranym okresie pojawiły się w zasadzie trzy istotne wydarzenia, które do takiej refleksji skłaniały dziennikarzy, a mianowicie: zmiana dyrektora programowego Trójki, upublicznienie kupionych zdjęć senatora Piesiewicza oraz dyskusja nad polską szkołą reportażu po publikacji książki Kapuściński non-fiction. Przeprowadzona analiza z pewnością nie jest wystarczająca, aby formułować jakiekolwiek dalekosiężne wnioski. Zauważalny jest jednak fakt, iż autorzy analizowanych tekstów ocenili standardy dziennikarskie zgodnie z zasadami spisanymi w Karcie Etycznej Mediów. $\mathrm{W}$ większości były to wypowiedzi zwracające uwagę na braki, wykroczenia przeciwko dobrze rozumianym standardom. Dostrzeganie tych niedociagnięć świadczy pozytywnie o polskich dziennikarzach. Ta krótka analiza pokazuje, iż dla niektórych dziennikarzy etos tego zawodu jest ciągle celem, do którego warto dążyć, piętnując jednocześnie zachowania niezgodne z nim.

Mój tekst chciałabym zakończyć słowami Ryszarda Kapuścińskiego, zawartymi w książce: Autoportret reportera. Tak mówi on o dobrym dziennikarstwie i dla mnie te słowa ciagle mają głęboki sens: Ideałem jest oczywiście całkowita niezależność, lecz życie jest dalekie od ideału [Kapuściński: 2003: 36].

\section{Bibliografia:}

Drożdż Michał, 2006, Etyczne orientacje w mediosferze, Byblos, Tarnów. Drożdż Michał, 2005, Media. Teorie i fikcje, Wydawnictwo Jedność, Kielce. 
Dyk Wiesław, 2002, Etyczny wymiar człowieka, Wydawnictwo Naukowe Uniwersytetu Szczecińskiego, Szczecin.

Dziamski Seweryn, 2005, Kultura $i$ etyka życia społeczno-zawodowego, Wydawnictwa Naukowe UAM, Poznań.

Kapuściński Ryszard, 2003, Autoportret reportera, Znak, Kraków.

Kwiatkowski Paweł, 1995, Niewiadomości. Rzecz o dziennikarzach, Dom Wydawniczy REBIS, Poznań.

Mariański Janusz, 2006, Socjologia moralności, Wydawnictwo KUL, Lublin.

McQuail Denis, 2008, Teoria komunikowania masowego, Wydawnictwo Naukowe PWN, Warszawa.

Nachmias David, Frankfort-Nachmias Chava, 2001, Metody badawcze w naukach społecznych, Zysk i S-ka, Poznań.

Nasalska Ewa, 1982, Kierunki rozwoju analizy treści, „Studia Socjologiczne”, nr 3-4.

Pisarek Walery (red.), 2006, Słownik terminologii medialnej, Universitas, Kraków.

Pleszczyński Jan, 2007, Etyka dziennikarska, Difin, Warszawa.

Sareło Zbigniew, 2007, Media w stużbie osoby. Etyka społecznego komunikowania, Wydawnictwo Adam Marszałek, Toruń.

Skrzypczak Józef (red.), 1999, Popularna encyklopedia mass mediów, Wydawnictwo Kurpisz, Poznań.

Sułek Mirosław, Świniarski Janusz, 2001, Etyka jako filozofia dobrego działania, Dom Wydawniczy Bellona, Warszawa.

Wimmer Roger D., Dominick Joseph R., 2008, Mass media. Metody badań, Wydawnictwo Uniwersytetu Jagiellońskiego, Kraków.

Brunetko Krzysztof, 2010, Nowa twarz Pana Ryszarda, „Polityka”, nr 11.

Czapiński Janusz, 2010, Wszystkie ręce na kołdrę, „Polityka”, nr 1.

Dziedzina Jacek, 2010, Przepis na BBC, „Gość niedzielny”, nr 4.

Geremek Rafał, Cieślik Mariusz, 2010, Reportaż z kluczem (w głowie), „Newsweek”, nr 13.

Grzeszczak Teresa, 2010, Obraz wart tysiqca słów, „Polityka”, nr 3.

Jakimowicz Marcin, 2010, Psim swędem, „Gość niedzielny”, nr 1.

Janicki Mariusz, Władyka Wiesław, 2010, Prasa na bruku, „Polityka”, nr 2.

Janicki Mariusz, Władyka Wiesław, 2010, PRL dla dorostych, „Polityka”, nr 13.

Krymowski Michał, 2010, Złote języki: ranking komentatorów politycznych, „Wprost”, nr 13.

Mikołejko Zbigniew, 2010, Zimne ślepia biowładzy, „Newsweek”, nr 8.

Najsztub Piotr, 2010, Ewangelia wg Pilota, „Przekrój”, nr 8.

Ozminkowski Violetta, 2010, Sorry Ziomale z Trójki, „Newsweek”, nr 3.

Paradowska Janina, 2010, Zabawa na Titanicu, „Polityka”, nr 11.

Pasternak Karolina, 2010, Zasypiałem z Kaczyńskim, „Przekrój”, nr 10.

Rolicki Janusz, 2010, Desakralizacja Kapuścińskiego, „Polityka”, nr 10. 
Ryciak Igor, 2010, Sternik z Trójka, „Przekrój”, nr 3.

Stankiewicz Andrzej, Śmiłowicz Piotr, 2010, Rekolekcje medialne, „Newsweek”, nr 10.

Stankiewicz Andrzej, 2010, Politycy - wynocha!, „Newsweek”, nr 10.

Szczepanik Krzysztof, 2010, Pani redaktor idzie na wojnę, „Przekrój”, nr 7.

Śmiłowicz Piotr, 2010, Orzet wyladowat, „Newsweek”, nr 1.

Walenciak Robert, 2010, Show czy propaganda?, „Przegląd”, nr 8.

Żakowski Jacek, 2010, Polityk, celebryta, banita, „Polityka”, nr 4.

Karta etyczna mediów, 1995, Warszawa.

Kodeks Etyki Dziennikarskiej Stowarzyszenia Dziennikarzy Polskich, 1995, Warszawa.

Kodeks Etyki Dziennikarzy SDRP, 2004, Warszawa.

Kodeks Etyki Dziennikarskiej KSD, 2004, Kołobrzeg.

\section{ETHOS JOURNALISTS - MYTH OR REALITY?}

\section{Summary}

This paper is an attempt to confront the opinion of Polish journalists, on the state of ethical principles in their operating environment to a set of rules in the Charter of Media Ethics. It tries to explain how, in the opinion of journalists, standards exist on paper are reflected in the daily journalistic work. The paper will be presented codes operating in the Polish media content analysis and the results of five leading weeklies Gość niedzielny, Polityka, Newsweek, Wprost, Przekrój, Przeglad on the cross section of the period from January to March 2010.

Key words: journalist, media, code of professional morality, trustworthiness. 